\title{
Some Tapes in the Wordship: Indexing the Audio Art Archives of Richard Kostelanetz
}

\author{
Alexis Bhagat \\ Independent Scholar \\ 99 Grand Street, Albany, NY 12202 USA \\ lex@nadalex.net
}

\begin{abstract}
This paper surveys of the audio collections in Wordship II, the home and studio of the artist-writer Richard Kostelanetz and describes a selection of titles included in a 1994 index called "Audio Art on Cassette". A few examples are described in detail in order to define the boundaries of the Audio Art collection.
\end{abstract}

Richard Kostelanetz, archives, audio art, mail art, sound poetry, bibliomanics, cassettes, audio publications

\section{RICHARD KOSTELANETZ AND HIS WORDSHIP}

Wordship II is the home and studio of artist and writer Richard Kostelanetz. Born in 1940 in New York, Richard Kostelanetz was a key critic of avantgarde art beginning in the 1960s, editing collections and anthologies of avant-garde literarture, and working to provide a critical foundation for areas of avant-garde art production, notably music, textsound, sound poetry, visual literature, book art, and concrete poetry. Kostelanetz's own artworks, in a variety of media but all based in a practice of writing, have been collected in two travelling exhibitions; the two together offer a summary description of Richard's practice. Wordsand: 19671978 was presented at Simon Fraser University in 1978 and travelled to the University of Alberta, Cornell College (Iowa, US), the University of North Dakota, Miami-Dade Community College, Vassar College and California State Univiersity at Bakersfield.

Wordsand, the traveling exhibition of my creative work with language in several media, includes spine-bound books of my visual poetry, visual fiction, experimental prose and numerical art; ladderbooks of visual fiction; card books whose pages can be distributed over an exhibition space; silkscreened prints; a poem on adding machine tape 50' long; offset cards; stereo audiotapes; color videotapes; $16 \mathrm{~mm}$. sound films; and several transmission holograms. (Kostelanetz, 2004)
Openings and C losings: The R ichard Kostelanetz Bookstore was presented by Kunstverein Amsterdam in 2011 and then expanded into More Wordship: $T$ he Richard K ostelanetz B ookstore which was exhibited by Kunstverein in Milan in 2013 and Lubliajana in 2018.

For reasons closely connected to Kostelanetz's practice we feel it is consistent that Kunstverein becomes a Bookstore dedicated to the artist-as a more viable alternative to a straight forward retrospective. Openings \& Closings - The Richard Kostelanetz Bookstore will host and sell all of RK's publications (over 80 titles). As well, rare artifacts, editions and smaller artworks will be on view in a secret backroom. (Kunstverein Amsterdam, 2011)

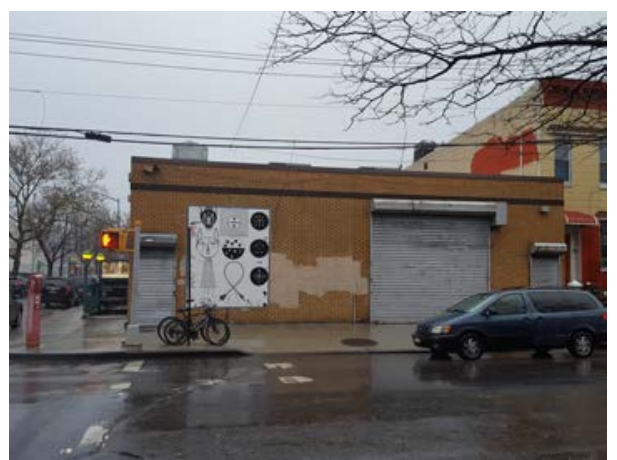

Figure 1: Exterior photo of Wordship II on Wyckoff Avenue in Ridgewood, NY. Photo by Alexis Bhagat, November 2017. 
The Wordship II, located in a former garment factory in Queens, New York, is named after an original Wordship, located in SoHo, where Kostelanetz lived from 1974 until 2009. In 1991, Kostelanetz wrote a long description of the Wordship and his library, ending with a very brief description of its name.

Each day that I can spend entirely at home, without ever leaving, I regard as a logistical success.... This devotion to my house is profound.... A few years ago, I gave it a name much like those given to British manor houses, because to me it is indeed a castle-Wordshipand christened myself its Earl. (Kostelanetz, 1991/2017)

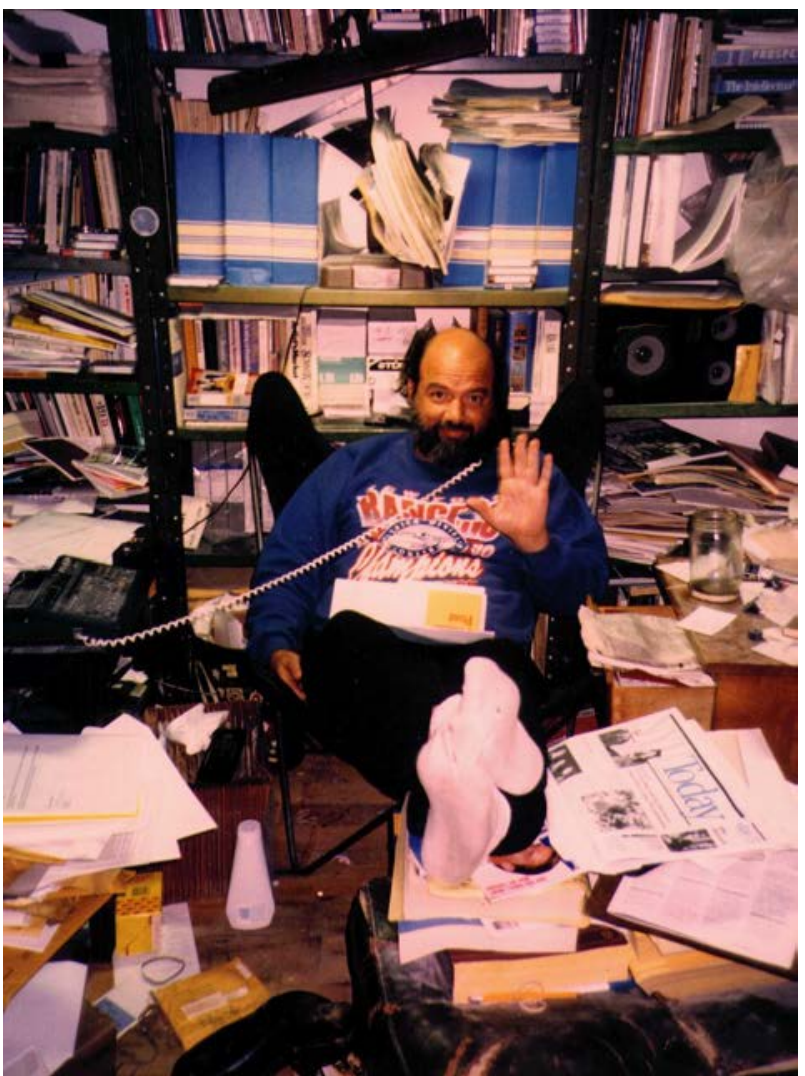

Figure 2: Richard Kostelanetz in the original Wordship located at 141 Wooster Street, New York City. Photo by Mary Jo Kline, 1991.

This story offers very little in terms of the meaning of the name: it is offered as an enigma, and the meanings which one ascribes often break around a first impression of the name as play on the aurally similar "worship", or as a compound word, "wordship." I take it as the latter. Jack Kerouac exhorted writers to swim in a sea of English; Kostelanetz dwells in a ship that sails the sea of words. A ship is made for the sea, for waters rough and smooth, for transportation to far shores. It is something that goes. Thus, for me, the name wordship also brings to mind the snails of Francis Ponge: "Snails go along glued bodily to first and second shells. I Clumped earth: Second shell. I They carry it with them, they eat it, they excrete it. / They go through it. It goes through them." (Ponge, 1997, p 38.)

The Wordship is literally full of words, primarily in books, also found on printouts, scraps of paper, magazines, holograms, video art, and sound recordings. The first Wordship contained perhaps 10,000 books, or "956 running feet" as Kostelanetz would cite with more precision (Kostelanetz, 2017). The much larger Wordship II has at least 25,000 books, firmly placing Kostelanetz in the clandestine confraternity of bibliomaniacs. (Killgannon, 2018).

"[Bibliomaniacs] can be divided into two principal categories: collectors and manic readers," writes the art historian and confessed bibliomaniac Jacques Bonnet. Collectors are acquisitive, readers are curious. Henry Folger (1857-1930), the authoritative collector of Shakespeare, and Antoine-Marie-Henry Boulard (1754-1825) a mayor of the VIIlth arrondissement of Paris who acquired 600,000 books, were collectors. Bonnet and Kostelanetz are readers.

Not that people in the first category don't read, but their chief interest lies elsewhere. And not that people in the second category don't accumulate books, but this is a consequence of their mania rather than their original intention. In their case, it starts with the itch to read and a wide-ranging curiousity, which does not necessarily imply book collecting, since they could always consult works in libraries, or borrow them, or sell them again after buying them. But the reading bibliomaniac wants to hold on to the physical object, to keep it ready at hand (Bonnet, 2010 p26).

Kostelanetz describes the same distinction, and a rationale for acquistion.

What the size of this library mostly reflects ... is not that I 'collect' books, because I don't, but that I've worked my way through several intellectual fields...A third, more personal fact is that my books are extensively annotated, not only with marks on their pages but also with sheets of paper filled with handwritten notes. When I want to find something that I remember being in any book of mine, I first consult these sheets. In a practical sense, these sheets and annotations are more valuable to me than the books; for unlike the books, they are irreplaceable. (Kostelanetz, 1991/2017)

Of course, the Wordship contains much more than books. As Kostelanetz pointed out in his 1991 article about the Wordship, "Most people entering my house for the first time will exclaim, 'So many books.' A few will say, 'So many records,' usually indicating that they are accustomed to seeing a lot of books." (Kostelanetz 1991/2017). This paper concerns some of those audiocassette tapes, which I found in the Wordship. 


\section{CRITICAL PROXIMITY, OR HOW I FOUND THE TAPES}

I happened to meet Richard Kostelanetz (who I will henceforth refer to in this paper as Richard) in a particular moment of his life, as he was preparing to move from the Wordship in Manhattan, to the Wordship II. Richard was a follower of the "don't throw anything away" philosophy, and he approached moving like that. Put everything into boxes and take it across intact.

I agreed to help Richard with the packing of the Wordship and reconstructed his library in the Wordship II. It was a process which took several years, during which Richard and I became very close. My project to catalog the audio collections in the Wordship is a product this critical proximity, to use a term from Jamie Allen's keynote lecture at the 2019 Media Art History conference:

Problems of knowledge and critique can be seen to be organized around this philosophical theme of proximity. Amongst the criteria of objectivity are that we get away from what we observe, out of or off of Earth, for example, in order to properly observe it - to see it as a whole and get the "necessary distance" that we suppose gives a clearer view. It is an abstraction that proceeds unabated and shows up everywhere: We are close to people whom we know well and feel comfortable and open with. (Allen, 2019)

This study was born from such proximity, from standing next to Richard day after day, packing and moving this very heavy library, and reconsistituting it in another building. One day in August 2018, Richard stood up from his work desk and together we looked at a wall of cassette tapes. "What is the purpose of this tape archive?" I asked.

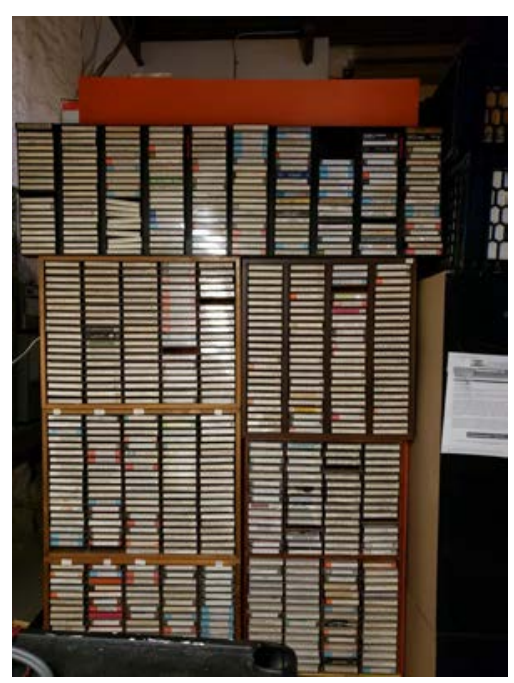

Figure 3: Photo of a portion of the cassette collection in Wordshop II by Alexis Bhagat, August 2018. All cassettes with call numbers appear on this shelf.

"You are going to make me cry," he said. "If I have to think about it, I will cry." These threatened tears point to the tragedy of any large collection: The Wordship, and everything within it, is extremely meaningful and valuable to Richard. Objectively, that is to say, to anyone else, it has far less value. The "irreplacable" handwritten notes in books are either illegible or have already been typed and collected in Richard's volume, One Million Words of $B$ ooknotes (1996). The magnetic media are already obsolete as a distribution format and are racing towards illegibility as well.

I asked Richard "please think about it: I'll give you a more specific question: look at these tapes. They are all decaying. Have you thought about migrating media? Are the recordings important to preserve?" Unable to answer, I asked him if his idea is simply to hold onto it in the hope that someday, someone else will sort through it?

Elatedly, he replied "you got it!" pointing out that now that has become his idea, but that, while acquiring them "all these tapes were just research for my own writings or compositions."

This undetermined question of the value of this collection is pertinent question to me, as one of the executors of his estate, and one that I am beginning to answer through a survey of the audio collections of the Wordship.

\section{SURVEYING THE AUDIO COLLECTIONS}

A broad survey of the audio collections in the Wordship revealed the following divisions:

- Published recordings of music (classical, avant garde, folk, rock, jazz) and spoken word (comedy, poetry, speeches) on LP, cassette, and CD

- Audio Art by Richard Kosetlanetz on 1/4" tape, DAT, and self-published cassettes

- Interview Recordings on 1/4" tape, DAT tape, cassette, and microcassette

- Recordings of television and radio Broadcasts, primarily on VHS tape, and also on cassette.

Cassette tapes were the only medium found in all four divisions of the audio collections. They are also found all through the Wordship: Cassette cases are bolted to the sides of the shelves upstairs, downstairs, and even in the kitchen. Cassettes are also in boxes stored throughout the house. Some were published by labels, but most were home-made tapes or from small artist editions. Some had call numbers on the side, or were shelved in racks with subject tage, for example, "Literary", "Popular Music," "German Horspiele", "Baseball" Others did not.

The cassettes drew me in as the best place to start. 


\section{THE AUDIOART ON CASSETTE INDEX}

In the past two decades I have accumulated many audiocassettes that have their own shelves. Some of these cassettes contain music; others transcriptions of classic American radio toward a projected book that never gets sufficient support. On one wall, in a crevice between two bookshelves, is a vertical stack of plastic cabinets of sound poetry/audio art; on another wall is a stack of the great modern writers reading their work (Kostelanetz 1991/2017).

Whn I asked Richard if he could explain the call numbers on some cassettes (but not others), he explained that these referred to an index created around 1994 called "Inventory of Audioart on Cassette." In February 2019, I began to compile all the tapes listed in the index. There are 240 tapes in total, arranged into rows $A, B, C$ and $B B$. As of September 2019, I have located approximately 150 cassettes.

The sources of the tapes include

- Published editions and compilations

- Cassette copies from 1/4" tape

- Artist produced tapes sent to RK

- Recordings of radio broadcasts or "cassette copies" from radio producers.

The general field of the AUDIOART CASSETTE collection includes a spread of poetry, radio art, sound collage, and experimental music practices which could generally be categorized as late 20th century avant-garde. In order to circumscribe this field, I shall briefly touch on some of the landmarks of the collection.

\subsection{Klaus Schöning and Charlie Morrow}

Cassettes A1 through A4 record a collaborative broadcast between Charlie Morrow and Klaus Schöning, and are titled by Richard as Klaus Schöning Introduces H örspiel 1988 and Introductions 1988 (Schöning, 1988). The recording includes definitions of horspiel and works by Bill Fontana, Ferdinant Kriwets, Mauricio Kagel, Erns Jandl \& Friedericke Mayrocker, Pauline Oliveros and Gerhard Ruhm. (The list here reflects Richard's typed annotations on cassette A4. There may be additional composers and producers on the cassette not listed on the notes.) These recordings were part of Charlie Morrow's annual International Summer Solstice International Radio Broadcast in 1988 (Morrow, 2014), which were broadcast annually on WNYC and with international partners beginning in 1981. Klaus Schonig established the WDR 3 HörSpielStudio in Koln in 1968, which later became the Studio Akustische Kunst in 1991.
Schöning commissioned more than 1000 hörspiele or sound art projects (Schöning, 2008). Many of the recordings in column A relate to Morrow and/or Schoning.

\subsection{Publications by Poets}

Column B includes a large number of recordings of sound poets, beginning with the cassette A1, Sound Poems by Patsy Rehn, and cassette A2, an untitled recording by Frances Alenikoff described by Richard with the comment "SONGS, CHANTS, SOUNDS, TAPE COLLAGE". Patsy Rehn is a poet, prose writer and actress, currently based in Bloomington, Indiana. Her sound poems were published in the jounral the A erial (Rehn, 2018). Frances Alenikoff was a choreographer and poet who founded the dance-studio Eden's Expressway in her loft at 537 Broadway in SoHo (Kostelanetz, 2003. Fox, 2012). Also in Column B are poetry publications by Toby Lurie include B43, Mirror Image, and B75, Volume II. Mr. Lurie also has a recording labeled $\mathrm{C} 19$, Trios. Toby Lurie is a living poet born in Seattle in 1925. He studied opera and composition in California after World War II, and settled in the Bay Area while a student at Mills College. He developed a form of sound poetry which he called "Word Music." Additional cassettes in Column B include what could be called the main stream of sound poetry - Henri Chopin and the various poets included in Chopin's definitive publication Poesie Sonore International. Cassettes B47 and B48 are the two cassettes that were published in 1979 as an addendum to Chopin's print volume. The cassettes include works by Françoise Barrière, Denis Chopin, Henry Chopin, Christian Adrien Clozier, John Cousins, Hugh Davies, François Dufrene, John Giorno, Lily Greenham, Brion Gysin, Sten Hanson, Bernard Heidsieck, Ernst Jandl, Léo Kupper, IImar Laaban, Tom Leonard, Arrigo Lora-Totino, Toby Lurie, Steve McCaffery, Franz Mon, Ladislav Novak, G Gerhard Ruhm, Steve Ruppenthal, Michel Seuphor, Paul De Vree, Larry Wendt (Chopin, 1979).

\subsection{Periodicals and Compilations}

The penultimate cassette in column B is B77, Glossolalia, issue 3 of a cassette periodical called Phonostatic, a companion to the xerox zine PhotoStatic founded and edited by Lloyd Dunn. PhonoStatic published 10 cassettes from 1984 to 1989 on a fairly regular six-month schedule (Dunn, 2014). Column C then begins with assorted issues of the Canadian radio art compilation Turbulence labeled cassette C1 through C5. Turbulence was "a collaborative radio project presented by two visual artists, Sam Krizan and Tony McAulay, who believe there to be a need 
to provide (alternative) radio which discusses the complexities of Art, for itself, and for its value in and to our society" (Kirzan and McAulay, 1983). Turbulence compilations were broadcast on CHRW from 1981 until at least 1986. The two hour mixes for radio were later published on cassette with their broadcast date.

Many of the editions in Column $\mathrm{C}$ for example Tellus the Audiocassette Magazine, which produced 25 issues from 1983 to 1993 , are periodicals, in the strict sense that they were published as serials on a more or less regular interval. The "VEC Audio Editions", labeled C60 through $\mathrm{C} 72$, were published 4 times per year, roughly every three months.

Published by Rod Summers in Maastricht, VEC Audio, or "Visual, Experimental, Concrete", produced two series - VEC Audio cassettes were produced in editions of 150 copies and were distibuted via barter.

\section{THE PROGRAMMES ARE AVAILABLE BY EXCHANGE. ONE PROGRAMME IN EXCHANGE FOR AN AUDIO WORK FROM YOU. Your cassette or tape will NOT be returned but will be included in the archive (Summers, 1978).}

\section{NEXT STEPS}

Locating the tapes in the index is an ongoing project. I am determining which tapes may be rare or unique, in order to prioritize which should be digitized. It is a multistep process, which begins with searching online discographies, starting with discogs.org, to determine which cassettes match official publications on LP. I assume all of those are home copies and not rare. The most important recordings I am trying to identify are artist produced studio recordings sent to Richard, which may not exist anywhere else. The large grey, of course, is with small edition cassette publications, which were "published" in editions of 100-500. For these small edition publications, I need to check with various archives to determine whether or not the recording has already been preserved.

Media artists of the $20^{\text {th }}$ century are the most important preservers of their work, and so I am contacting them directly as part of this indexing. An exhibition called "Audiomail" at the Fahrenheit 451 House in Catskill, NY provides a platform for me to write to artists about their work in Richard Kostelanetz's archive, and to invite them to send a recording of their choice to be preserved by the Fahrenheit 451 House Library.

AUDIOMAIL is a year long collaborative project of Alexis Bhagat and Christophe Albertijn that invites a variety of informal audio archives to contribute to the Fahrenheit 451 House (F451) library. During one year musicians, labels, sound artists, poets, radio producers and others will be contributing to AUDIOMAIL by mailing recordings from their own work or archives to the F451 library using mailers designed for this project. (Albertijn and Bhagat, 2019)

One archive feeding into the creation of another.

\section{REFERENCES}

Albertijn C and A Bhagat (2019) "Audiomail Project Description",

https://fahrenheit451house.com/\#/audiomailfirsty ear (Retrieved September 14, 2019).

Allen, J (2019) "Beyond the Media Reveal: Full of Sound and Fury, Signifying... What?", Media Art History c onference, 20-23 August, Aalborg University.

Chopin, H (1979) Poésie sonore internationale, J$M$ Place, Paris.

Dunn, L (2014) "A Brief History of the PhotoStatic Project", http://psrf.detritus.net/texts/brief_history.html (Retrieved September 14, 2019).

Fox, M (2012) "Frances Alenikoff, 91, Dancer and Visual Artist", New York Times, July 9, p A20. https://www.nytimes.com/2012/07/09/arts/dance/ frances-alenikoff-dies-at-91-founder-of-2dance- companies.html (Retrieved September 14, 2019).

Killgannon, C (2018) "His Fortress, a PageTurner", New Y ork T imes, April 8, p MB4. https://www.nytimes.com/2018/04/04/nyregion/t $\mathrm{h}$ e-bibliomaniac-of-ridgewood.html (Retrieved September 14, 2019).

Kirzan S and T McAulay, (1983) Turbulence, \#78 [Audio Cassette], London, Ontario. (Liner notes).

Kostelanetz, R (2017) My House Wordship, Redux Lit Journal, http://www.reduxlitjournal.com/2017/07/237my- house-wordship-by-richard.html (Retrieved September 14, 2019). Previously published in Southwest Review (1991) and Home and Away (1991).

Kostelanetz, R (2004) "Proposals: Wordsand exhibition", author's official website, http://richardkostelanetz.com/prop/exwordsan d (Retrieved August 14, 2019).

Kostelanetz, R (2003) Soho, Routledge, New York. Kunstverein Amsterdam (2011) Press Release for Kunstverein Amsterdam exhibtion, e-flux,https:// www.eflux.com/announcements/35427/opening sand-closings-the-richard-kostelanetzbookstore/ (Retrieved September 14, 2019). 
Lurie, T (2018) "Biography", https://w3art.com (Retrieved August 14, 2019).

Lurie, T (2013) "A Life", http://tobypoet.com (Retrieved August 5, 2018).

Morrow, C (2014) "Milestones", http://www.charliemorrow.com/milestones.ht ml (Retrieved August 14, 2019).

Ponge, F (1997) Selected Poems, translated by Margaret Gutton, John Montague, and C.K. Williams, edited by Margaret Gutton, Wake Forest University, Winston-Salem, NC, USA.
Rahn, P (2018) "About", author's official website, https://www.patsyrahn.com/about (Retrieved August 14, 2019).

Schöning, K (1988) Klaus Schöning introduces New Wilderness Hörspiel [3 audio cassettes] Charles Morrow Associates, New York.

Schöning, K (2008) "Klaus Schöning: Leben und Wirken", author's official website, https://www.klaus-schoening.de/lw.html (Retrieved August 15, 2019). 